\title{
Effectiveness of coffee leaf miner control associated with spray deposition in coffee leaves ${ }^{1}$
}

\author{
Renan Zampiroli $^{2 *}$ (D), Cleyton Batista de Alvarenga ${ }^{2}$, Paula Cristina Natalino Rinaldi ${ }^{2}$, Vanessa Andaló ${ }^{2}$, \\ Jair Rocha do Prado Pablo Arthur Silva Gonçalves $^{2}$
}

10.1590/0034-737X202067050007

\begin{abstract}
Coffee production faces challenges due to the susceptibility of the crop to insects. Owing to the coffee leaf miner Leucoptera coffeella, which is one of the main insect pests, the technology for the application of phytosanitary measures becomes the main challenge for coffee growers. This study aimed to evaluate the effectiveness of coffee leaf miner control using different methods of application. The study was conducted in an experimental site in the municipality of Monte Carmelo - Minas Gerais. Spray depositions in different positions of the plant canopy and the effective control of coffee leaf miner were evaluated using the following application treatments: a hydropneumatic sprayer with varying spray volumes (200 and $400 \mathrm{~L} \mathrm{ha}^{-1}$ ), two hollow-cone spray nozzles with the presence and absence of agricultural adjuvant, and electrostatic application using a spray volume of $200 \mathrm{~L} \mathrm{ha}^{-1}$ with and without spray adjuvant. The addition of an adjuvant to the spray did not influence coffee leaf miner control; in contrast, a spray volume of $200 \mathrm{~L} \mathrm{ha}^{-1}$ combined with the application of coarse droplets was efficient in the management of insect pest. The reduction in the rate of the application using coarse droplets increased the operational capacity and reduced spray drift potential.
\end{abstract}

Keywords: Leucoptera coffeella; electrostatic; adjuvant; hydropneumatic sprayer.

\section{INTRODUCTION}

Brazil is the world's largest producer and exporter, and the second-largest consumer of coffee. The estimated production of the 2018 harvest season was approximately 61.7 million $60 \mathrm{~kg}$ bags (arabica and conilon) (Conab, 2019).

Coffee farmers face numerous challenges due to the occurrence of pathogens and insects in plantations (Carvalho et al., 2012); a major insect pest is the coffee leaf miner, Leucoptera coffeella (Guérin-Mèneville \& Perrottet, 1842) (Lepidoptera: Lyonetiidae) (Costa et al., 2015). After L. coffeella eggs hatch on the leaf surface, the caterpillars penetrate the leaf through the epidermis, feeding on the palisade parenchyma and causing up to $70 \%$ defoliation (Scalon et al., 2013).

Hydropneumatic sprayers are used extensively in coffee plantations (Sousa Júnior et al., 2017b). According to Iost \& Raetano (2010), application effectiveness can be improved by using specific adjuvants. As stated by Silva et al. (2014), in addition to the spray nozzles, the spray volumes adopted during applications should aim to wet the leaves considerably while avoiding spray loss due to soil drainage. Decaro Júnior et al. (2015), while analyzing the effect of reduced spray volumes in coffee leaf miner control, found that a spray volume of $200 \mathrm{~L} \mathrm{ha}^{-1}$ achieved an insect control effectiveness of $80 \%$.

An alternative technology to hydropneumatic application in coffee plantations is the electrostatic application. Sasaki et al. (2013a) demonstrated that electrostatic application increased spray deposition by $37 \%$ when compared to conventional application systems. According to Minguela \& Cunha (2010), in the electrostatic application, the droplets produced by the spray tips have their charge altered by the addition or removal of electrons, depending on the electric field

\footnotetext{
Submitted on March 16th, 2020 and accepted on July $20^{\text {th }}, 2020$.

${ }^{1}$ This work is part of the master's thesis of the first author.

${ }^{2}$ Universidade Federal de Uberlândia campus Monte Carmelo, Instituto de Ciências Agrarias, Monte Carmelo, Minas Gerais, Brazil. renanzampiroli@ufu.br; cleytonalvarenga@ufu.br; paularinaldi@ufu.br; vanessaandalo@ufu.br; jairrp@ufu.br; pabloasgoncalves@gmail.com

*Corresponding author: renanzampiroli@ufu.br
} 
generated by induction rings that receive high voltage from a generator system.

The present study aimed to evaluate the effectiveness of coffee leaf miner control using hydropneumatic and electrostatic spraying methods based on different spray volumes and spray nozzles, with and without the addition of an agricultural adjuvant.

\section{MATERIAL AND METHODS}

The experiments were conducted within the premises of the Machinery and Mechanization Laboratory (LAMM), Institute of Agricultural Sciences of the Federal University of Uberlândia, Monte Carmelo Campus on an experimental site in Santa Bárbara farm (18 46214.813 $\mathrm{S}$ and $47^{\circ} 3325.613 \mathrm{~W}$ ).

The monitoring activity was according to a methodology adapted from Zampiroli et al. (2017); each plot was monitored separately, including the controls without insecticide application. A leaf in the third or fourth pair of plagiotropic branches was observed at the median height of the plant, on the north and south surfaces, where 60 leaves were sampled per plot, summing up to 240 leaves per treatment. Plants of the Mundo Novo cultivar aged five years were grown with a spacing of $3.5 \mathrm{~m}$ between rows and $0.9 \mathrm{~m}$ between plants.

Control effectiveness was determined according to Abbott's (1925) effectiveness equation and infestation was monitored up to 14 days after application, which corresponded to the period of activity of the insecticide (Equation 1).

$\mathrm{EF}=\frac{\mathrm{Ll}_{1}-\mathrm{Ll}_{2}}{\mathrm{Ll}_{1}} 100$

on what:

$\mathrm{EF}=$ Efficiency $(\%)$;

$\mathrm{Ll}_{1}=$ Live larvae in the control area (\%);

$\mathrm{Ll}_{2}=$ Live larvae in the treatments (\%).

This was done by getting the ratio of the percentage of live larvae in the treatments to the percentage of live larvae in the control area where no insecticide was applied.

The experiment adopted a randomized block design arranged in a $2 \times 2 \times 2+2$ factorial design with four replicates. In the hydropneumatic application system, the effects of two spray volumes (200 and $400 \mathrm{~L} \mathrm{ha}^{-1}$ ), two spray nozzles (JA-01 and TVI-800075, Jacto, Pompeia, São Paulo, Brazil) with the absence and presence of adjuvant in the insecticide were evaluated. Four control plots without insecticide were maintained in the site to determine control effectiveness.

The active ingredients present in the insecticide spray was Cartap hydrochloride at $500 \mathrm{~g}$ a.i. ha ${ }^{-1} y ́$ and orange oil

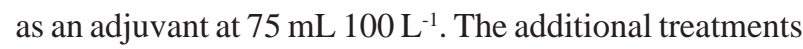

were electrostatic application system in the absence and presence of the adjuvant, at a spray volume of $200 \mathrm{~L} \mathrm{ha}^{-1}$ using an SPE-2 hollow-cone spray nozzle made of ceramic. The electric field was generated at the jet base from the electrification of the stainless steel cylindrical ring in the nozzle.

To better distribute the blocks and decrease the potential migratory effects of insects, the spacing between the blocks was $34 \mathrm{~m}$, with the blocks at each end of the area reserved for border planting. Fifty plants were used in each treatment to monitor the coffee leaf miner populations, of which 30 central plants were useful while the other 20 at both ends were considered as border plants. The spacing between the plots within each block was $7 \mathrm{~m}$.

The sprayers were driven and activated by a Valtra 685 tractor with a nominal power of $47.8 \mathrm{~kW}$. The rotation speed of the power take-off was $540 \mathrm{rpm}$, measured using a digital photo/contact tachometer (MDT2238A, Minipa, São Paulo, Brazil).

A hydropneumatic sprayer (Arbus $2.000 \mathrm{VM}$, Jacto, Pompéia, Brazil) equipped with a piston pump (JP-150) with a flow rate of $150 \mathrm{~L} \mathrm{~min}^{-1}$ and an axial fan with a turbine diameter of $850 \mathrm{~mm}$ was used for spraying. A WIKA manometer (AG, Switzerland) with a range of 0-40 $\mathrm{kgf} \mathrm{cm}{ }^{-2}$ was used to control the working pressure of the spraying system. In the hydropneumatic system, the boom sprayer had a semicircular shape with two branches of 12 nozzles on each side, totaling 24 nozzles. In the electrostatic system, the electrostatic spray kit (SPE-2) was composed of seven nozzles on both branches, with a total of 14 nozzles. It is developed and marketed by the Sistema de Pulverização Eletrostático Company.

The operational conditions for regulating and calibrating the sprayers had been previously determined and the speeds were measured where the experiments were conducted with both spray volumes (Table 1).

After the insecticide application, a method adapted from Sasaki et al. (2013a) was used; where two leaves were collected in each position for evaluating spray deposition, totaling 48 leaves per treatment. The central plants of the plot were divided into three canopy heights (upper, middle, and lower), and each height section was subdivided into two positions called external and internal positions.

The leaves were packed in previously tagged plastic bags and transported to the laboratory where they were washed using $30 \mathrm{~mL}$ of distilled water and agitated for 30 seconds to remove the dye (Miranda et al., 2012). The deposition was measured using a spectrophotometer (V5000, Shanghai Metash Instruments Co., Ltd. Shanghai, China) by the adsorption of the Brilliant Blue marker (FD\&C n.1) added to the spray at a concentration of $4.0 \mathrm{~g}$ $\mathrm{L}^{-1}$ at a wavelength of $630 \mathrm{~nm}$. 
The dye volume captured by the target was determined by the ratio of the dye concentration in the solution after sample washing and that obtained in the spray volume. Subsequently, dye concentrations were determined by dividing the total deposition by the leaf surface area (Sasaki et al., 2013b) using an LI-3100C leaf area meter (LI-COR Biosciences, NE, USA).

The statistical analyses were performed using $R(R$ Core Team, 2019). The data satisfied the normality assumptions of the Shapiro-Wilk test (W) residues and homogeneity of Anscombe and Tukey variances tests. Analysis of Variance was performed using the F test at 95\% confidence level.

\section{RESULTS AND DISCUSSION}

The meteorological conditions during the application were monitored using a portable weather station (WMR200, Oregon Scientific, Portland, OR, USA) and the results obtained reads a mean temperature of $29^{\circ} \mathrm{C}$, mean relative air humidity of $37 \%$, and mean wind speed of 4.3 $\mathrm{km} \mathrm{h}^{-1}$, monitored using a portable weather station. Although the atmospheric conditions were not ideal, spraying was carried out owing to the high level of infestation in the area, with an average of $65 \%$ live larvae. In addition, at that time of the year (spring)—characterized by high temperature, low relative humidity, and the highest infestation levels of coffee leaf miner-coffee plantations were attacked by several pests causing coffee farmers to anticipate weather conditions considered ideal to commence spraying. Therefore, the alternative use of appropriate application technologies to control pest was adopted.

While evaluating spray depositions at different canopy positions, a significant effect on the interaction among the absence and presence of an adjuvant, spray nozzle, and spray volume was observed at the middle height and internal position as well as the upper height and external depth of the branch. In the median and upper external positions, the interaction between the additional treatments and the factorial had a significant effect. Also, in the median and the upper internal positions, there were significant effects among the additional treatments. The mean deposition obtained in the additional treatments differed from that obtained in the treatments with a TVI800075 nozzle and a spray volume of $400 \mathrm{~L} \mathrm{ha}^{-1}$ (Table 2).

Since the electrostatic spraying system produces extremely fine droplets, there is a possible influence of weather conditions on spray deposition via evaporation. As described by Alvarenga et al. (2014), droplets with relatively small diameters are more susceptible to environmental factors such as temperature, relative humidity, and wind action.

There was significant interaction among adjuvant factors, spray nozzle, and spray volume in the deposition of dye at the internal position of the branch characterized as median height. Electrostatic spraying, in turn, decreased deposition when the adjuvant was added (Table 3 ).

A higher dye deposition with an increase in spray volume was also observed by Sousa Júnior et al. (2017a). The results were different from those reported by Silva $e t$ al. (2014), who stated that spray penetration and deposition was facilitated by an ATR nozzle (fine to extremely fine droplets) because it produced droplets with smaller diameter based on a volume of $200 \mathrm{~L} \mathrm{ha}^{-1}$ as compared to spraying with a volume of $500 \mathrm{~L} \mathrm{ha}^{-1}$. According to Cunha et al. (2017), the addition of adjuvants in a spray could alter the performance of insecticide application, positively or negatively influencing deposition on a target.

When spraying at a rate of $200 \mathrm{~L} \mathrm{ha}^{-1}$ with adjuvant, the JA-1 nozzle deposited approximately $44 \%$ less dye than the TVI nozzle. Droplets with small diameters resulted in a higher load/mass ratio. Furthermore, according to Minguela \& Cunha (2010), the addition of an adjuvant, and some formulations, could influence the electrification process.

Table 1: Operational conditions for each treatment

\begin{tabular}{|c|c|c|c|c|c|}
\hline Treatment & Gear & $\begin{array}{c}\text { Speed } \\
\left(\mathbf{k m ~ h}^{-1}\right)\end{array}$ & $\begin{array}{c}\text { Flow } \\
\left(\mathrm{L} \mathrm{min}^{-1}\right)\end{array}$ & $\begin{array}{l}\text { Pressure } \\
(\mathbf{k P a})\end{array}$ & $\begin{array}{l}\text { Spray volume } \\
\quad\left(\mathrm{L} \mathrm{ha}^{-1}\right)\end{array}$ \\
\hline $\mathrm{T} 1$ & 3RD RED & 7.8 & 0.379 & 593 & 200 \\
\hline $\mathrm{T} 2$ & 2ND RED & 3.8 & 0.369 & 565 & 400 \\
\hline $\mathrm{T} 3$ & 3RD RED & 7.8 & 0.379 & 593 & 200 \\
\hline $\mathrm{T} 4$ & 1ST SIM & 5.8 & 0.564 & 1.241 & 400 \\
\hline T5 & 3RD RED & 7.8 & 0.379 & 593 & 200 \\
\hline T6 & 2ND RED & 3.8 & 0.369 & 565 & 400 \\
\hline $\mathrm{T} 7$ & 3RD RED & 7.8 & 0.379 & 593 & 200 \\
\hline $\mathrm{T} 8$ & 1ST SIM & 5.8 & 0.564 & 1.241 & 400 \\
\hline T9 & 3RD RED & 7.8 & 0.630 & 965 & 200 \\
\hline $\mathrm{T} 10$ & 3RD RED & 7.8 & 0.630 & 965 & 200 \\
\hline
\end{tabular}

RED - Reduced gearbox; SIM - Single gearbox 
The interaction between the spray nozzle, spray volume, and the absence and presence of an adjuvant influenced dye deposition in the upper external third position of the branch, both in the conventional and the additional treatments (Table 4 ).

In the application of $400 \mathrm{~L} \mathrm{ha}^{-1}$ using the JA-1 nozzle, the deposition was approximately $29 \%$ higher in the presence of an adjuvant than in its absence. As observed by Chechetto et al. (2013), when compared with the other adjuvants, the addition of vegetable oil adjuvant at a concentration of $1 \%$ using a flat pre-orifice nozzle reduced spray drift.

The use of the TVI-800075 nozzle in the highest spray volume of insecticide containing an adjuvant resulted in the reduction of dye deposition by $21 \%$. This is because a decrease in surface tension increases runoff of coarse droplets; therefore, the TVI-800075 nozzle enhanced deposition in all the treatments, including the additional treatments in the absence of the adjuvant. As stated by Cunha et al. (2017), adjuvants may have diverse effects, altering the physical and chemical properties of the sprays, particularly decreasing the surface tension of droplets.

Despite the addition of adjuvants, the deposition observed following the use of the electrostatic system did not differ from the deposition observed in the hydropneumatic system using a spray volume of $200 \mathrm{~L}$ $\mathrm{ha}^{-1}$ and a JA-1 nozzle; and without the adjuvant and using a spray volume of $400 \mathrm{~L} \mathrm{ha}^{-1}$. Different results were

Table 2: Mean dye deposition $\left(\mu \mathrm{L} \mathrm{cm}{ }^{2}\right)$ in the outer median third of the branch as a function of the nozzle and adjuvant

\begin{tabular}{lccccc}
\hline \multirow{2}{*}{ Nozzle } & \multicolumn{5}{c}{ Adjuvant x Spray volume (L ha ${ }^{-1}$ ) } \\
\cline { 2 - 3 } & \multicolumn{2}{c}{ Absence } & & \multicolumn{2}{c}{ Presence } \\
\cline { 2 - 3 } \cline { 5 - 6 } & $\mathbf{2 0 0}$ & $\mathbf{4 0 0}$ & & $\mathbf{2 0 0}$ & $\mathbf{4 0 0}$ \\
\hline JA-1 & $0.41 \mathrm{aA} \beta$ & $0.88 \mathrm{aA} \beta$ & & $0.56 \mathrm{aA} \beta$ & $0.87 \mathrm{aA} \beta$ \\
TVI-800075 & $0.47 \mathrm{aA} \beta$ & $0.98 \mathrm{aA} \alpha$ & & $0.74 \mathrm{aA} \beta$ & $1.06 \mathrm{aA} \alpha$ \\
\hline SPE without adjuvant & & & $0.60 \beta$ & \\
SPE with adjuvant & & & $0.58 \beta$ & \\
\hline CV & & 25 & \\
\hline
\end{tabular}

Means followed by different lower-case letters in the column; upper-case letters in the row differ from each other by the Tukey test, and Greek letters differ from each other in relation to the additional treatments by the Dunnett test $(\mathrm{p}>0.05)$.

Table 3: Mean dye deposition $\left(\mu \mathrm{L} \mathrm{cm}^{2}\right)$ at the median height of the branch as a function of adjuvant, spray volume, and nozzle

\begin{tabular}{|c|c|c|c|c|}
\hline \multirow{3}{*}{ Adjuvant } & \multicolumn{4}{|c|}{ Nozzle x Spray volume $\left(\mathrm{L} \mathrm{ha}^{-1}\right)$} \\
\hline & \multicolumn{2}{|c|}{ JA-1 } & \multicolumn{2}{|c|}{ TVI-800075 } \\
\hline & 200 & 400 & 200 & 400 \\
\hline Absence & $0.46 \mathrm{aB}$ & $0.86 \mathrm{aA}$ & $0.49 \mathrm{aB}$ & $0.80 \mathrm{aA}$ \\
\hline Presence & $0.32 \mathrm{aC}$ & $0.85 \mathrm{aA}$ & $0.57 \mathrm{aB}$ & $0.67 \mathrm{aAB}$ \\
\hline \multirow{2}{*}{\multicolumn{2}{|c|}{ Adjuvant x Nozzle }} & & \multicolumn{2}{|c|}{ Spray volume (L ha-1) } \\
\hline & & & 200 & 400 \\
\hline \multirow{2}{*}{ Absence } & \multirow{2}{*}{$\begin{array}{c}\text { JA-1 } \\
\text { TVI-800075 }\end{array}$} & \multicolumn{2}{|r|}{$0.46 \mathrm{abB}$} & $0.86 \mathrm{aA}$ \\
\hline & & \multicolumn{2}{|r|}{$0.49 \mathrm{abB}$} & $0.80 \mathrm{aA}$ \\
\hline \multirow{2}{*}{ Presence } & JA-1 & \multicolumn{2}{|r|}{$0.32 \mathrm{bB}$} & $0.85 \mathrm{aA}$ \\
\hline & TVI-800075 & \multicolumn{2}{|r|}{$0.57 \mathrm{aA}$} & $0.67 \mathrm{aA}$ \\
\hline \multirow{2}{*}{\multicolumn{2}{|c|}{ Adjuvant x Spray volume $\left(\mathrm{L} \mathrm{ha}^{-1}\right)$}} & & \multicolumn{2}{|c|}{ Nozzle } \\
\hline & & & JA-1 & TVI-800075 \\
\hline \multirow{2}{*}{ Absence } & 200 & \multicolumn{2}{|r|}{$0.46 \mathrm{bA}$} & $0.49 \mathrm{bA}$ \\
\hline & 400 & \multicolumn{2}{|r|}{$0.86 \mathrm{aA}$} & $0.80 \mathrm{aA}$ \\
\hline \multirow{2}{*}{ Presence } & 200 & \multirow{2}{*}{\multicolumn{2}{|c|}{$\begin{array}{l}0.32 \mathrm{bB} \\
0.85 \mathrm{aA}\end{array}$}} & $0.57 \mathrm{bA}$ \\
\hline & 400 & & & $0.67 \mathrm{abB}$ \\
\hline \multicolumn{2}{|c|}{ SPE without adjuvant } & \multicolumn{3}{|c|}{$0.73 \alpha$} \\
\hline \multicolumn{2}{|c|}{ SPE with adjuvant } & \multicolumn{3}{|c|}{$0.45 \beta$} \\
\hline \multicolumn{2}{|l|}{$\overline{\mathrm{CV}(\%)}$} & \multicolumn{3}{|c|}{18} \\
\hline
\end{tabular}

Means followed by different lower-case letters in the column; upper-case letters in the row differ from each other by the Tukey test, and Greek letters differ from each other in relation to the additional treatments by the Dunnett test $(p>0.05)$. 
observed by Gitirana Neto et al. (2016) after evaluating spray deposition in mountain coffee. They reported that the use of electrostatic technology and the use of silicone adjuvant at a spray volume of $200 \mathrm{~L} \mathrm{ha}^{-1}$ resulted in a higher deposition which improved application effectiveness.

Regardless of the presence of the adjuvant, a spray volume of $400 \mathrm{~L} \mathrm{ha}^{-1}$ enhanced deposition with levels higher than those obtained using a spray volume of $200 \mathrm{~L}$ $\mathrm{ha}^{-1}$. However, a reduction in the deposition was observed in the largest volume containing orange oil adjuvant. A similar effect was observed when the additional treatments were evaluated, with a reduction in spray deposition owing to the use of the orange oil adjuvant (Table 5).

The higher levels of deposition in the upper internal third position were because of the lower levels of evaporation observed when using coarse droplets such as those resulting from the adoption of larger spray volumes, which was enhanced by the adjuvant at a spray volume of $400 \mathrm{~L} \mathrm{ha}^{-1}$. Silva et al. (2014) obtained similar results at spray volumes of 200 and $500 \mathrm{~L} \mathrm{ha}^{-1}$ for spray deposition in the upper third canopy position of coffee plants with and without air induction. According to Gabriel \& Baio (2013), the use of a surfactant adjuvant as a component of sprays may influence spray deposition and droplet size.

The electrostatic application of a spray with an orange oil adjuvant decreased dye deposition by approximately
$33 \%$ when compared with the electrostatic application without adjuvant. Such results indicate a potential interaction between the adjuvant and the electrostatic spray system. Different results were observed by Gitirana Neto et al. (2016) using the electrostatic application and an adjuvant with a spray volume of $200 \mathrm{~L} \mathrm{ha}^{-1}$.

The effectiveness of coffee leaf miner control was influenced by the interaction between the spray nozzle and spray volume. The means of the effectiveness of coffee leaf miner control when adjuvants were applied compared to the controls without adjuvants indicate that a spray volume of $200 \mathrm{~L} \mathrm{ha}^{-1}$ and using a TVI-800075 nozzle offered better coffee leaf miner control than when using the JA-1 nozzle. Conversely, at a spray volume of $400 \mathrm{~L}$ $\mathrm{ha}^{-1}$, the situation was reversed (Table 6).

The higher control efficiency results from the interaction between the $200 \mathrm{~L} \mathrm{ha}^{-1}$ volume and the hydropneumatic spraying with the TVI hydraulic tip, not differing from the additional treatments. The results suggest that a spray volume of $200 \mathrm{~L} \mathrm{ha}^{-1}$ is sufficient considering the technical, economic, and environmental aspects necessary for the management of the coffee leaf miner. The reduction in the rate of the application using coarse droplets, in addition to allowing greater operational capacity, mitigates the potential risk of drift.

After reaching an infestation index of $65 \%$ live larvae before spraying, the control effectiveness was considered

Table 4: Mean dye deposition $\left(\mu \mathrm{L} \mathrm{cm}^{-2}\right)$ in the upper outer third of the branch as a function of adjuvant, spray volume, and nozzle type

\begin{tabular}{|c|c|c|c|c|}
\hline \multirow{3}{*}{ Adjuvant } & \multicolumn{4}{|c|}{ Nozzle x Spray volume (L ha-1) } \\
\hline & \multicolumn{2}{|c|}{ JA-1 } & \multicolumn{2}{|c|}{ TVI-800075 } \\
\hline & 200 & 400 & 200 & 400 \\
\hline Absence & $0.33 \mathrm{aC} \beta$ & $0.77 \mathrm{bB} \beta$ & $0.46 \mathrm{aBC} \beta$ & $1.12 \mathrm{aA} \alpha$ \\
\hline Presence & $0.39 \mathrm{aB} \beta$ & $0.99 \mathrm{aA} \alpha$ & $0.53 \mathrm{aB} \beta$ & $0.88 \mathrm{bA} \alpha$ \\
\hline \multirow{2}{*}{\multicolumn{3}{|c|}{ Adjuvant x Nozzle }} & \multicolumn{2}{|c|}{ Spray volume $\left(\mathrm{L} \mathrm{ha}^{-1}\right)$} \\
\hline & & & 200 & 400 \\
\hline \multirow{2}{*}{ Absence } & \multicolumn{2}{|c|}{ JA-1 } & $0.33 \mathrm{aB} \beta$ & $0.76 \mathrm{bA} \beta$ \\
\hline & TVI-800075 & & $0.46 \mathrm{aB} \beta$ & $1.12 \mathrm{aA} \alpha$ \\
\hline \multirow{2}{*}{ Presence } & \multirow{2}{*}{$\begin{array}{c}\text { JA-1 } \\
\text { TVI-800075 }\end{array}$} & & \multirow{2}{*}{$\begin{array}{l}0.39 \mathrm{aB} \beta \\
0.53 \mathrm{aB} \beta\end{array}$} & \multirow{2}{*}{$\begin{array}{l}0.99 \text { abA } \alpha \\
0.88 \text { abA } \alpha\end{array}$} \\
\hline & & & & \\
\hline \multirow{2}{*}{\multicolumn{3}{|c|}{ Adjuvant x Spray volume ( $\left.\mathrm{L} \mathrm{ha}^{-1}\right)$}} & \multicolumn{2}{|c|}{ Nozzle } \\
\hline & & & JA-1 & TVI-800075 \\
\hline \multirow{2}{*}{ Absence } & 200 & \multicolumn{2}{|r|}{$0.33 \mathrm{bA} \beta$} & $0.46 \mathrm{bA} \beta$ \\
\hline & & \multicolumn{2}{|r|}{$0.76 \mathrm{aB} \beta$} & $1.12 \mathrm{aA} \alpha$ \\
\hline \multirow{2}{*}{ Presence } & & \multirow{2}{*}{\multicolumn{2}{|c|}{$\begin{array}{l}0.39 \mathrm{bA} \beta \\
0.99 \mathrm{aA} \alpha\end{array}$}} & $0.53 \mathrm{bA} \beta$ \\
\hline & & & & $0.88 \mathrm{aA} \alpha$ \\
\hline SPE witho & & & 0.5 & \\
\hline SPE with a & & & 0.4 & \\
\hline $\mathrm{CV}(\%)$ & & & 2 & \\
\hline
\end{tabular}

Means followed by different lower-case letters in the column; upper-case letters in the row differ from each other by the Tukey test, and Greek letters differ from each other in relation to the additional treatments by the Dunnett test $(p>0.05)$. 
Table 5: Mean dye deposition $\left(\mu \mathrm{L} \mathrm{cm}^{2}\right)$ in the upper internal third of the branch as a function of spray volume and adjuvant

\begin{tabular}{|c|c|c|}
\hline \multirow{2}{*}{ Spray volume ( $\left.\mathrm{L} \mathrm{ha}^{-1}\right)$} & \multicolumn{2}{|c|}{ Adjuvant } \\
\hline & Absence & Presence \\
\hline 200 & $0.33 \mathrm{bA}$ & $0.40 \mathrm{bA}$ \\
\hline 400 & $0.69 \mathrm{aA}$ & $0.56 \mathrm{aB}$ \\
\hline SPE without adjuvant & \multicolumn{2}{|c|}{$0.60 \alpha$} \\
\hline SPE with adjuvant & \multicolumn{2}{|c|}{$0.40 \beta$} \\
\hline$\overline{\mathrm{CV}(\%)}$ & \multicolumn{2}{|c|}{21} \\
\hline
\end{tabular}

Means followed by different lower-case letters in the column; uppercase letters in the row differ from each other by the Tukey test, and Greek letters differ from each other in relation to the additional treatments by the Dunnett test $(\mathrm{p}>0.05)$.

Table 6: Control effectiveness (\%) of coffee leaf miner larvae using different hydraulic nozzles and spray volumes

\begin{tabular}{lcc}
\hline \multirow{2}{*}{ Nozzle } & \multicolumn{2}{c}{ Spray volume $\left(\mathbf{L ~ h a}^{-\mathbf{1}}\right)$} \\
\cline { 2 - 3 } & $\mathbf{2 0 0}$ & $\mathbf{4 0 0}$ \\
\hline JA-1 & $53 \mathrm{bB} \alpha$ & $65 \mathrm{aA} \alpha$ \\
TVI-800075 & $70 \mathrm{aA} \alpha$ & $56 \mathrm{bB} \alpha$ \\
\hline SPE without adjuvant & \multicolumn{2}{c}{$57 \alpha$} \\
SPE with adjuvant & \multicolumn{2}{c}{$65 \alpha$} \\
\hline CV $(\%)$ & \multicolumn{2}{c}{15} \\
\hline
\end{tabular}

Means followed by different lower-case letters in the column; uppercase letters in the row differ from each other by the Tukey test, and Greek letters differ from each other in relation to the additional treatments by the Dunnett test $(\mathrm{p}>0.05)$.

satisfactory, particularly with the $200 \mathrm{~L} \mathrm{ha}^{-1}$ spray volume and using the TVI-800075 nozzle. Decaro Júnior et al. (2015) found that a spray volume of $200 \mathrm{~L} \mathrm{ha}^{-1}$ obtained using a conventional sprayer with nozzles that produce fine droplets, and a spray volume of $92 \mathrm{~L} \mathrm{ha}^{-1}$ obtained using a sprayer with Ultra Low-Volume (ULV) provided insecticide deposition and L. coffeella control effectiveness greater than $80 \%$.

The results suggest that the use of coarse droplets is a suitable alternative for coffee growers managing coffee leaf miner, particularly during winter when the relative humidity of the air in the cerrado of Minas Gerais is very low. Although the use of air nozzles under such conditions decreases drift due to evaporation, in the field, only nozzles that produce fine droplets are suitable for the management of insects and pathogens in coffee plantations.

\section{CONCLUSION}

The use of agricultural adjuvant did not influence the control effectiveness of coffee leaf miner. At a spray volume of $200 \mathrm{~L} \mathrm{ha}^{-1}$, the TVI nozzle provided greater control than the JA nozzle. Electrostatic spraying was as efficient as hydropneumatic spraying. The reduction in the application rate using coarse droplets increased the operational capacity and reduced drift potential.

\section{ACKNOWLEDGEMENTS}

The authors would like to thank the Brazilian Federal Agency for Support and Evaluation of Graduate Education (Coordenação de Aperfeiçoamento de Pessoal de Nível Superior - CAPES), the National Council for Scientific and Technological Development (Conselho Nacional de Desenvolvimento Científico e Tecnológico - CNPq), the Minas Gerais State Research Support Foundation (Fundação de Amparo à Pesquisa do Estado de Minas Gerais - Fapemig), Jacto S. A. and Suprema Agronegócios, for their support in this project.

\section{REFERENCES}

Abbott WS (1925) A method of computing the effectiveness of an insecticide. Journal of Economic Entomology, 18:265-267.

Alvarenga CB, Teixeira MM, Zolnier S, Cecon PR, Siqueira DL, Rodriguês DE, Sasaki RS \& Rinaldi PCN (2014) Efeito do déficit de pressão de vapor d'água no ar na pulverização hidropneumática em alvos artificiais. Bioscience Journal, 30:182-193.

Carvalho VL, Cunha RL \& Silva NRN (2012) Alternativas de controle de doenças do cafeeiro. Coffee Science, 7:42-49.

Chechetto RG, Antuniassi UR, Mota AAB \& Carvalho FK (2013) Influência de pontas de pulverização e adjuvantes no potencial de redução de deriva em túnel de vento. Ciências Agrárias, 34:37-46.

CONAB - Companhia Nacional de Abastecimento (2019) Acompanhamento da safra brasileira (café): Quarto levantamento Safra 2018. Available at: http://www.conab.gov.br. Accessed on: September $15^{\text {th }}, 2019$

Costa FM, Alves GF, Scalon JD \& Zacarias MS (2015) Análise estatística das distribuições espaciais do bicho-mineiro do cafeeiro e das vespas predadoras. Coffee Science, 10:149-157.

Cunha JPAR, Alves GS \& Marques RS (2017) Surface tension, hydrogen-ion potential and electrical conductivity in spray solutions of plant protection products and adjuvants. Revista Ciência Agronômica, 48:261-270.

Decaro Júnior ST, Ferreira MC, Lasmar O \& Fouquet G (2015) Reducing spray volume for the control of Leucoptera coffeella (Lepidoptera: Lyonetiidae) in coffee plants. Coffee Science, 10:491-498.

Gabriel RRF \& Baio FHR (2013) Interação entre pressão e tamanho de gota por instrumentação eletrônica em pulverizador pressurizado por $\mathrm{CO}_{2}$. Pesquisa Agropecuária Tropical, 43:164169.

Gitirana Neto J, Cunha JPAR, Marques RS, Lasmar O \& Borges EB (2016) Deposição de calda promovida por pulverizadores empregados na cafeicultura de montanha. Coffee Science, 11:267275 .

Iost CAR \& Raetano CG (2010) Tensão superficial dinâmica e ângulo de contato de soluções aquosas com surfactantes em superfícies artificias e naturais. Engenharia Agrícola, 30:670680 .

Minguela JV \& Cunha JPAR (2010) Manual de aplicação de defensivos agrícolas. Viçosa, Aprenda Fácil. 588p.

Miranda GRB, Raetano CG, Silva VC, Cunha MDQ, Carvalho RH, Pinheiro JM, Gonçalves MP, Reinato CHR, Paiva LC \& Araújo D (2012) Avaliação dos depósitos da pulverização em frutos de cafeeiro utilizando dois equipamentos associados a diferentes volumes de calda. Revista Agrogeoambiental, 4:15-20. 
R Development Core Team (2010) R: A Language and environment for statistical computing. Available at: <https://www.Rproject.org/>. Accessed on: March 20"th 2019.

Sasaki RS, Teixeira MM, Fernandes HC, Monteiro PMB, Rodrigues DE \& Alvarenga CB (2013a) Parameters of electrostatic spraying and its influence on the application efficiency. Revista Ceres, 60:474-479.

Sasaki RS, Teixeira MM, Fernandes HC \& Monteiro PMB (2013b) Deposição e uniformidade de distribuição da calda de aplicação em plantas de café utilizando a pulverização eletrostática. Ciência Rural, 43:1605-1609.

Scalon JD, Mateus ALSS \& Zacarias MS (2013) Análise espaçotemporal do nível de infestação do bicho-mineiro Leucoptera coffeella, (Guérin-Menèville \& Perrottet, 1842) (Lepidoptera: Lyonetiidae) em cafezal orgânico (Coffea arabica L.). Coffee Science, 8:347-353.
Silva JER, Cunha JPAR \& Nomelini QSS (2014) Deposição de calda em folhas de cafeeiro e perdas para o solo com diferentes taxas de aplicação e pontas de pulverização. Revista Brasileira de Engenharia Agrícola e Ambiental, 18:1302-1306.

Sousa Júnior JM, Ruas RAA, Duarte LO, Faria VR, Carvalho Filho A \& Santos Júnior CR (2017a) Influência da densidade foliar na distribuição de calda no dossel do cafeeiro (Coffea arabica L.). Coffee Science, 12:216-222.

Sousa Júnior JM, Ruas RAA, Silva CD, Faria VR, Carvalho Filho A \& Vieira LC (2017b) Determinação do índice de volume de pulverização para a cultura do café. Coffee Science, 12:82-90.

Zampiroli R, Alvarenga CB, Carvalho VAM, Rinaldi PCN \& Assis GA (2017) Application technology for chemically controlling coffee leaf-miner in the cerrado of Minas Gerais State. Revista de Ciências Agrárias, 60:256-262. 